\section{Towards a Languages Policy for New Zealand Education}

\author{
RICHARD BENTON
}

\section{Abstract:}

Although a national languages policy had not yet been formulated, developments during 1994 indicated that at least some of the key recommendations of the 1992 discussion document Aoteareo: Speaking for Ourselves had been incorporated in official policy. Draft curriculum statements were launched for Spanish, English, Chinese (Mandarin) and Maori (including mathematics and science taught through Maori). Both the Minister of Education and the Prime Minister stressed the economic importance of developing competence in key foreign languages among New Zealanders. Some attention was paid to community languages but major emphasis was given to commercially significant foreign languages, English and Maori. Although the position of Maori as an official language seemed to be universally recognised and assured, serious deficiencies in the effectiveness of measures being taken to revitalise the language were highlighted. Among these, inadequacies in teacher-training and resource development attracted comment from Maori groups and from several official agencies.

ince the publication of Aoteareo: Speaking for Ourselves (Waite, 1992a,b), New Zealand educators have been awaiting the appearance of an explicitly formulated statement of national languages policy which would set broad strategic directions, linking language learning and teaching to other areas of activity - commerce, trade, tourism, diplomacy, and social and cultural development. Although some state-funded research has elaborated on the themes set out in Aoteareo and extended the recommendations implicit in that report (Peddie, 1993), the grand plan has yet to be announced.

Nonetheless, some evidence of the evolution of a coherent languages policy in education at least emerged in the course of 1994. In general, this policy seems to be in accord with the tentative priorities listed by the Minister of Education in his introduction to Aoteareo (Waite, 1992b:4), which, in relation to education, had already been affirmed by the New
162 Richard Benton

Zealand Curriculum Framework's section on language (Ministry of Education, 1993a). These were:

- opportunities for all children and adults to learn English;

- the development of skills in major international languages;

- supporting Maori as an official language of New Zealand;

- increasing the levels of adult literacy in the workplace;

- enabling ethnic communities to maintain their own languages; and

- access to social services for all New Zealanders, including those with communication difficulties.

\section{English in the Curriculum}

The release in December 1994 of the definitive curriculum statement for English (Ministry of Education, 1994h) directly addressed the first of these priorities, and indirectly the fourth as well. It marked the culmination of a process of consultation and debate extending over several years, and frequently marked by acrimony. Perhaps the most notable example of the latter kind of response was the extended commentary on the penultimate draft, published early in 1994 by the Business Roundtable's Education Forum. The Forum's assertions that the new curriculum proposals were the continuation of "a progressive undermining of academic content" associated with an emphasis on "individual therapy" (Education Forum, 1994:21) did not, however, strike a sympathetic chord with the Minister of Education. In his "State of the Nation's Education" address in February, the Minister foresaw a "Custer's Last Stand attempt to undermine the quite unique public confidence in the curriculum and qualifications reforms", and warned that:

I take a dim view of some of the criticism we have heard recently about the science and English curriculum statements - criticism which was badly researched, and attacked straw-men rather than anything actually in the statements themselves (Smith, 1994a:7).

The final statement (the Education Forum's assertions notwithstanding) set out guidelines for a comprehensive approach to the study and use of English at all levels of the primary and secondary school systems, including phonology, morphology, syntax and semantics along with the study of literature, discourse analysis, the social and cultural aspects of language, the development of critical thinking and the mastery of a wide range of skills in visual communication as well as in the traditional written and oral modes of language use. 


\section{Languages Other Than English or Maori}

In the same address the Minister reaffirmed his policy of approving five new Kura kaupapa Maori a year, and announced that new, comprehensive curriculum guidelines would be issued for Maori language and mathematics and science taught through Maori, Samoan, Spanish and Chinese. All these materials had been published by the end of the year (Ministry of Education, 1994b-g). Furthermore, Dr Smith noted that "research shows the links between the foreign language abilities of nations and their foreign trade potential" (Smith, 1994a:5), and stated his intention to investigate whether foreign language teaching could be strengthened in intermediate and junior secondary schools, and indeed whether study of at least one language other than English or Maori could be made compulsory at this level. In May, when he launched the promised guidelines for Spanish and Chinese, the Minister reaffirmed his commitment to the teaching of foreign languages in New Zealand, and stated that, while a shortage of teachers made it unlikely that the idea of compulsory second language study would be proceeded within the immediate future, it was more likely that schools would be required to offer a second language to all students from forms 1 to 4 , with compulsion on students a matter for the schools themselves to decide (1994b).

While affirming the importance of cultural and intellectual considerations (and noting that he himself had won a Pushkin Prize as a student), Dr Smith stressed the need "to reflect the changes in New Zealand's international trading situation by including the languages and cultures of our Asian trading partners." Similar remarks on the importance of second language learning for New Zealanders now and in the future were made by the Prime Minister while in Malaysia at about the same time (ERO, 1994b:4). Commerce and diplomacy were clearly more important than the maintenance of ethnic mother tongues in the choice of Mandarin as the "standard" form of "Chinese" within the New Zealand curriculum. The Minister did acknowledge the "pressure by New Zealand's larger Cantonese-speaking community", and suggested that a curriculum statement for Cantonese could be prepared "when other curriculum statements have been completed" (Smith, 1994b:3). On the other hand, Samoan, a community language which is the ethnic mother tongue of about 2 percent of the New Zealand population, and may now have a larger number of fluent speakers than Maori, did gain its own curriculum statement (Ministry of Education, $1994 \mathrm{~g}$ ) and a place among subjects included in the national secondary school examinations for the first time.
The Education Review Office (ERO) released a study of second language provision in New Zealand schools in which several key areas of concern were identified: learning opportunities for students (time, availability starting point); maintaining interest (militated against where the emphasis was on gaining a qualification rather than on enjoyment); staffing (identified as a national issue, but also an area where boards of trustees could "act strategically" by encouraging language teachers to retrain in languages - like Spanish and Pacific Island languages - "likely to be sought by future students"). A perceived elite status of foreign language studies in secondary schools had been noted with concern, as an inhibiting factor in attracting more students; it was suggested that this was primarily a function of the "organisation of the curriculum" (ERO, 1994b:15). This report was launched with a press statement from the Secretary of Commerce (ERO, 1994a), underlining the need for more speakers of commercially important languages.

\section{Te Reo Maori}

Maori language remained in sharp focus throughout the year. In March, the Secretary of Education, Dr Maris O'Rourke, emphasised the importance of the Maori language as "a treasure, or taonga, implicitly guaranteed protection in Article II of the Treaty of Waitangi, and recognised in law as an official language", and reported on the steps which had been taken within the education system to support its revitalisation (O'Rourke, 1994a). Explicit mention was made of the importance of increasing the amount of printed and recorded material, and developing the vocabulary base along with this, to support the expansion and consolidation of the language in new domains. The impending publication of a comprehensive draft curriculum statement for Maori language in Maori-medium schools was noted, along with the corresponding draft science and mathematics statements. These were all published in Maori without English translations (itself a significant policy statement) later in the year (Ministry of Education, 1994b,c,d).

However, the curriculum statements alone could not guarantee that their objectives would be met, and the lack of sufficient well-qualified teachers for Maori-medium programmes remained a "critical issue". The Ministry's report on strategic direction for Maori education in 1994/95 noted that many Maori teacher trainees were not fluent in Maori and did not train to teach through the medium of Maori; at secondary level, those competent in Maori generally had no other subject specialisation. "Specific quality programmes" were needed to address these issues (Ministry of Education, 1994a:21). 
Although the document contained no specific proposals for establishing such programmes, it did link the renaissance of the Maori language with "greater involvement and success by young Maori in the education system", which in turn, it claimed, was "bringing new life and energy to the language" (ibid:36). Support for initiatives such as Kura kaupapa Maori therefore continued to be high on the Ministry's agenda. In 1993, just under 10 percent of the 15,500 Maori children in primary level immersion programmes were attending Kura kaupapa Maori. By the beginning of 1994, 28 Kura kaupapa Maori catered for 1667 students (O'Rourke, 1994a:2). Altogether, about 16 percent of Maori children were receiving a substantial part of their education through Maori, while 84 percent were not. Clearly, access to an education through Maori was still a very limited good.

The Maori Language Commissioner, Professor Timoti Karetu, attracted considerable media interest when he informed the Parliamentary Select Committee on Maori Affairs that he had "serious concerns about the effectiveness and accountability of Maori language initiatives, including kura kaupapa and kohanga reo." There was an "information gap" about the effectiveness of these measures, because no research had been undertaken to evaluate their linguistic outcomes. In May the Wellington Evening Post reported comments he had made to the Parliamentary Select Committee on Maori Affairs under the front-page headline "Up to $\$ 300$ million 'wasted' on Maori lessons" (Evening Post, 1994). However, a press release from the Commission the following day pointed out that Professor Karetu's remarks did not mean that the initiatives were failing or that the money was being wasted. It did mean however, that measurements of the benefits derived from them were essential to facilitate forward planning for these Maori language initiatives (Maori Language Commission, 1994a).

The Commission was able to obtain funds to begin planning for a follow-up to the sociolinguistic survey of Maori language use which had been undertaken by the New Zealand Council for Educational Research (NZCER) in the 1970s. It also prepared an action plan for a national language policy in the public sector (Maori Language Commission, 1994b). Wide support was gained for the Commission's plan to declare 1995 Te Tau o te Reo Maori (Maori Language Year). At the ceremony to formally launch the Year, held at Parliament Buildings on December 13, the Chief Executive of the Ministry of Maori Development (Te Pun Kokiri) issued a press release stating that "Te Puni Kokiri has always held the promotion of the language as a key priority underpinning Maor development, particularly in the field of educational endeavour." The "shortage of Maori language teachers and the lack of Maori language education resources" were mentioned explicitly as areas needing special attention. This concern was shared by the Education Review Office, which in its 1993/4 Annual Report noted that "some schools would not be willing or able to provide Maori language tuition" without special funding (which could possibly be removed from such schools under targetting policies), and "the shortage of skilled teachers able to teach the curriculum in both Maori and English" was a cause of special concern. There were too few to meet the current demand, and colleges of education were not producing enough graduates skilled in both languages to meet future needs (ERO, 1994c:15-16).

\section{English for Speakers of Other Languages}

Although the 1991 Census showed that in the period 1986-91 there had been marked increases in the populations of many Asian and Pacific ethnic groups resident in New Zealand (the Chinese community, for example, constituted 1.1 percent of the total population, compared with 0.6 percent in 1986), 93 percent of New Zealand residents were still of either Maori or European descent in 1991, and 93.4 percent had been born in an English-speaking country (84.2 percent in New Zealand, 1.5 percent in Australia, 7.2 percent in the British Isles, and 0.5 percent in Canada, the U.S. or South Africa). Nonetheless, multilingualism had become an issue which many New Zealand schools were having to deal with on a daily basis. According to Ministry of Education statistics, there were 46,700 children from "non-English speaking backgrounds" (excluding Maori-speakers and foreign fee-paying students) in New Zealand schools in 1993,1915 of whom could speak no English at all, up from 1304 in 1992 (Ministry of Education, 1993b, 1994i; Atkinson, 1992). Only 13,000 of these pupils were considered able to "read, write and speak English competently" and thus to need no additional special support to enable them to cope with the school programme. There were 3 to 4,000 students at each class level, half to a third of whom in the intermediate and senior classes, and almost all of whom in the first two years of the junior school, were considered to be in need of comprehensive help to cope with oral and/or written English.

The Ministry of Education was well aware of these needs, and announced in March that it would be calling for proposals to expand special teacher development programmes in the 1995 school year (O’Rourke, 1994b:2). Under policies in force up to and including 1994, schools had also been given "equity funding" by the Ministry of Education to enable them to develop programmes for pupils with special needs. 
Under new policy proposals, however, special funding will be made available only to schools located in districts identified by the Department of Statistics as having relatively high proportions of economically needy families. Several Wellington schools with large numbers of Samoan pupils who had English as a second language were reported as being likely to lose funding for their learner support programmes under the new policy as their socio-economic decile rating was too high (Woods, 1994). The reason for the change in policy was not clear; a Ministry spokesperson reportedly described it as "more objective". On the surface, it would appear to have been motivated more by administrative convenience (where "objective" indicators replace the need for personal decision-making) than by considerations of equity, at least as this relates to individuals.

Meanwhile, community language groups and teachers of English as a second language continued to meet with each other annually, following the 1991 conference that led to the development of Aoteareo. Their 1994 conference in Christchurch attracted a large number of participants who gave presentations on a wide variety of topics. Although many of these presentations addressed practical pedagogical and administrative issues, one dealt directly with languages policy in New Zealand (Peddie and Lo Bianco, 1994), and several appeared to touch on policy-related issues (e.g., Fetui, 1994; Syme, 1994; Tongatio, 1994; Grenfell and Johnson, 1994; Love, 1994; Kasanji, 1994; Boyce and Smith, 1994; Crombie, 1994).

\section{Micro-Level Policies}

Over the last few decades, a small number of New Zealand schools have been pro-active in developing language policies of their own, anticipating longer-term needs as well as meeting immediate and obvious ones. Richmond Road School in Auckland is an outstanding example of such a school, and the development and implementation of its programme, which recognised and fostered education through Maori, English and several community languages, along with highly innovative approaches to teaching, administration and school/community relations over a ten-year period have been well documented (Cazden, 1989; Corson, 1993; May, 1991, 1994a, 1994b). However, such cases are rare, and attempts to institute serious and sustained policy formulation along the lines advocated by Corson (1990; also MacPherson \& Corson, 1989) and practised at Richmond Road seem often to have foundered either through apathy or sheer busyness with other matters on the part of overworked principals and staff members (see MacPherson, in press, for a recent example of this). On the national level, pre-school education shows greatest recognition of the place of heritage languages of immigrants from other parts of Polynesia. In, 1993, 177 Polynesian language nests, catering for 3,877 children, were receiving government funding. Formal curriculum guidelines had been developed for Samoan, and by 1994 the languages of the major Polynesian communities were taught in at least a few secondary schools.

\section{Conclusion}

While New Zealand seemed to be evolving a national languages policy in education at an appreciable rate in 1994, there was still little evidence of the kind of coordinated strategic planning which had been advocated in the Aoteareo report. Assumptions were still being made on the basis of wishful thinking or popular wisdom rather than solid research. For example, although "immersion" education is given considerable prominence, there is as yet no research to indicate whether, given the acute shortage of teachers, delayed immersion programmes might not be a more effective way of transmitting the language in those communities where there are no Maori-speaking families, than attempts to start at the pre-school level and struggle through the early years with inadequate resources and teachers whose command of the language may also need considerable strengthening. Similarly, the stress on the role of the secondary school in teaching foreign languages, although wellmotivated, overlooks the fact that for many individuals the language learned at school may not be the one they need most in their working life as diplomats or traders. If widespread foreign language proficiency related to New Zealand's commercial and strategic interests is to be achieved, as much stress should perhaps be placed on developing strong and easily accessible conventional and intensive language courses at the tertiary level as on expanding foreign language teaching in the secondary schools.

From the Maori viewpoint, although access to education through the Maori language is now an option for a growing minority of children, the progress that has been made is still unsatisfactory given the endangered state of the language in its only homeland. This was underlined in a colour photograph and accompanying account on a front page of the Dominion newspaper in November, describing a march of 3,000 people through the streets of the capital to Parliament on 31 October. The marchers were protesting against the "Government's lack of commitment to Maori language", resulting in inadequate funding and resources and the small number of qualified Maori language teachers. Very similar complaints had been aired at a demonstration of the same kind at the 
same place in 1972 (Benton, 1981:50), an event recalled with nostalgia by some of those who spoke at the launch of Te Tau o te Reo Maori, with the anxieties underlying the rally of 1972 still painfully present in the consciousness of others who had participated in both events.

All in all, although 1994 brought some substantial leaps forward in the development and implementation of an implicit national languages policy in education, it did little to dispel the impression that Ranko Bugarski's description of language policy in (the former) Yugoslavia was actually written with New Zealand in mind:

A major structural weakness of this policy is its lack of coherence and of firm institutional foundations. At the federal [read "national"] level it exists mainly as a body of general principles, to be made operative in rather diverse and uncoordinated ways at successive lower levels, with little systematic institutional care or real control (1991:21).

\section{References}

Atkinson, A. Non-English Speaking Background Students in New Zealand Schools. Wellington: Data Management Section, Ministry of Education, 1992.

Benton, R. A. The Flight of the Amokura: Oceanic Languages and Formal Education in the South Pacific. Wellington: New Zealand Council for Educational Research, 1981.

Boyce, M. \& Smith, H. "Language issues in the Lao refugee community of Wellington", 1994.

Bugarski, R. "Language situation and general policy", in R. Bugarski and C. Hawkesworth (eds) Language Planning in Yugoslavia, Columbus, Ohio: Slavica, 1991:10-26.

Cazden, C. "Richmond Road: A multilingual/multicultural primary school in Auckland, New Zealand", Language and Education 3, 1989:143-166.

Corson, D. Language Policy across the Curriculum. Clevedon: Multilingual Matters Ltd, 1990.

Corson, D. Language, Minority Education and Gender: Linking Social Justice and Power. Clevedon: Multilingual Matters Ltd \& Toronto: Ontario Institute for Studies in Education, 1993.

Crombie, W. "Quality assurance and professional standards in TESOL", Paper presented at the Fourth Community Languages and TESOL
Conference, Christchurch College of Education, September 1994.

Department of Statistics. 1991 Census of Population and Dwellings: National Summary. Wellington, 1992.

Department of Statistics. 1991 Census of Population and Dwellings: New Zealand's Multicultural Society. Wellington, 1993.

Dominion (Wellington), 1 November 1994.

Education Forum. English in the New Zealand Curriculum: A Submission on the Draft. Auckland, 1994.

Education Review Office (ERO). "Students urged to become multilingual", Media release, 8 September, Wellington, 1994a.

Education Review Office (ERO). Second Language Learning (National Educational Evaluation Reports No. 6), Wellington, 1994b.

Education Review Office (ERO). Annual Report, Wellington: House of Representatives, 1994c.

Evening Post (Wellington), 26 May, 1994.

Fetui V. "Samoan in the New Zealand Curriculum", Paper presented at the Fourth Community Languages and TESOL Conference, Christchurch College of Education, September, 1994.

Grenfell, J. \& Johnson, B. “Bi-culturalism, multiculturalism, a big issue for all of us", Paper presented at the Fourth Community Languages and TESOL Conference, Christchurch College of Education, September, 1994.

Kasanji, L. "Ethnic language schools", Paper presented at the Fourth Community Languages and TESOL Conference, Christchurch College of Education, September, 1994.

Love, P. "Community languages - baskets or burdens?" Paper presented at the Fourth Community Languages and TESOL Conference, Christchurch College of Education, September, 1994.

Macpherson, J. In press, Making Changes: Action Research for Developing Maori Language Policies in Mainstream Schools. Wellington: NZCER.

Macpherson, J. and Corson, D. LPAC:Language Policy across the Curriculum, Eight Case Studies of School-Based Policy Development. Palmerston North: Department of Education, Massey University, 1989. 
Maori Language Commission (Te Taura Whiri i Te Reo Maori), Press release on Evening Post article of 26 May, issued May 27. Wellington, $1994 a$.

Maori Language Commission (Te Taura Whiri i Te Reo Maori), "Blueprint for a languages policy: New Zealand Public Service", (Document released by the Commission, May.) Wellington, 1994b.

May, S. "Making the difference for minority children: The development of an holistic language policy at Richmond Road School, Auckland, New Zealand", Language, Culture and Curriculum 4, 1991:201-217.

May, S. Making Multicultural Education Work, Clevedon, Multilingual Matters, 1994a.

May, S. "School-based language policy reform: A New Zealand example", In A. Blackledge (ed.), Teaching Bilingual Children (19-41), Stoke-on-Trent: Trentham Books, 1994b.

Ministry of Education. The New Zealand Curriculum Framework/Te Anga Matauranga o Aotearoa. Wellington: 1993a.

Ministry of Education. Education Statistics of New Zealand, Wellington: $1993 b$.

Ministry of Education. Nga Haeata Matauranga (Ministry of Education Annual Report 1993/4 and Strategic Direction for Maori Education 1994/5), Wellington: Ministry of Education, 1994a.

Ministry of Education. Te Reo Maori, Te Tuaki Matauranga: He Tauira. Wellington: Te Pou Taki Korero, 1994b.

Ministry of Education, Pangarau, Te Tuaki Matauranga: He Tauira. Wellington: Te Pou Taki Korero, 1994c.

Ministry of Education, Putaiao, Te Tuaki Matauranga: He Taura. Wellington: Te Pou Taki Korero, 1994d.

Ministry of Education, Spanish in the New Zealand Curriculum: Draft. Wellington: Learning Media, 1994e.

Ministry of Education. Chinese in the New Zealand Curriculum: Draft. Wellington: Learning Media, $1994 \mathrm{f}$.

Ministry of Education. Samoan in the New Zealand Curriculum: Draft/ Ta'iala mo le Gagana Samoa i Niu Sila: Tusitusiga Fa'ata'ita'i. Wellington: Learning Media, 1994g.
Ministry of Education. English in the New Zealand Curriculum. Wellington: Learning Media, 1994h.

Ministry of Education. Education Statistics of New Zealand. Wellington, $1994 \mathrm{i}$.

Ministry of Maori Affairs (Te Puni Kokiri), "Te Puni Kokiri to lend full support to Maori Language Year in 1995" (Media statement released December 13), Wellington, 1994.

O'Rourke, M. "Revitalisation of the Maori language", New Zealand Education Gazette 73.3:1-2, 1994a.

O'Rourke, M. "Language and languages in the New Zealand curriculum", New Zealand Education Gazette 73.4:1-2, $1994 \mathrm{~b}$.

Peddie, R. A. From Policy To Practice: The Implementation of Languages Policies in Victoria, Australia, and New Zealand, Auckland: Centre for Continuing Education, University of Auckland, 1993.

Peddie, R. A. with Lo Bianco, J. “National languages policy: where do we go from here?" Paper presented at the Fourth Community Languages and TESOL Conference, Christchurch College of Education, September, 1994.

Smith, L. "State of the Nation's Education", (Address to Rotary Club of Wellington Central, 15 February). Speech notes supplied by the Office of the Minister of Education. Wellington, 1994a.

Smith, L. Speech notes for launch of draft Chinese and Spanish curriculum statements, 10 May, (Interoffice memorandum supplied by Office of the Minister of Education), Wellington, 1994b.

Syme, P. "Intensive or mainstream for new learners of English at secondary school?" Paper presented at the Fourth Community Languages and TESOL Conference, Christchurch College of Education, September, 1994.

Tongatio, L. "Language is culture, together we stand, divided we fall", Paper presented at the Fourth Community Languages and TESOL Conference, Christchurch College of Education, September, 1994.

Waite, J. Aoteareo: Speaking for Ourselves Part A: The Overview, Wellington: Learning Media, 1992a.

Waite, J. Aoteareo: Speaking for Ourselves Part B: The Issues, Wellington: $1992 \mathrm{~b}$. 
Towards a Languages Policy for New Zealand Education 173

Woods, G. "Needy pupils suffer from funding cuts", Evening Post (Wellington), 5 October 1994.

\section{The author}

Richard Benton coordinates the Maori research programme of the New Zealand Council for Educational Research and is an Honorary Lecturer in Linguistics at Victoria University of Wellington. He has written extensively on bilingual and minority education, language policy and the maintenance and revitalisation of indigenous languages. 